Prepared in cooperation with the U.S. Environmental Protection Agency

\title{
Water-Quality Distributions in the East Branch Black River near the Chemical Recovery Systems Site in Elyria, Ohio, 2021
}

Open-File Report 2021-1086 



\section{Water-Quality Distributions in the East Branch Black River near the Chemical Recovery Systems Site in Elyria, Ohio, 2021}

By Jordan L. Wilson and Edward G. Dobrowolski

Prepared in cooperation with the U.S. Environmental Protection Agency

Open-File Report 2021-1086 


\section{U.S. Geological Survey, Reston, Virginia: 2021}

For more information on the USGS - the Federal source for science about the Earth, its natural and living resources, natural hazards, and the environment-visit https://www.usgs.gov or call 1-888-ASK-USGS.

For an overview of USGS information products, including maps, imagery, and publications, visit https://store.usgs.gov/.

Any use of trade, firm, or product names is for descriptive purposes only and does not imply endorsement by the U.S. Government.

Although this information product, for the most part, is in the public domain, it also may contain copyrighted materials as noted in the text. Permission to reproduce copyrighted items must be secured from the copyright owner.

Suggested citation:

Wilson, J.L., and Dobrowolski, E.G., 2021, Water-quality distributions in the East Branch Black River near the Chemical Recovery Systems site in Elyria, Ohio, 2021: U.S. Geological Survey Open-File Report 2021-1086, 10 p., https://doi.org/10.3133/ofr20211086.

Associated data:

Wilson, J.L., and Dobrowolski, E.G., 2021, Autonomous underwater vehicle water-quality and sonar measurements in the East Branch Black River near Elyria, Ohio, 2021: U.S. Geological Survey data release, https://doi.org/10.5066/ P9FEBCBY.

U.S. Geological Survey [USGS], 2021, USGS 04200500 Black River at Elyria OH, in USGS water data for the Nation: U.S. Geological Survey National Water Information System database, accessed April 12, 2021, at https://doi.org/ 10.5066/ F7P55KJN. [Site information directly accessible at https:/ /waterdata.usgs.gov/oh/nwis/uv?site_no=04200500.]

ISSN 2331-1258 (online) 


\section{Acknowledgments}

Funding for this work was provided by the U.S. Environmental Protection Agency Region 5. 



\section{Contents}

Acknowledgments ……...................................................................................................................

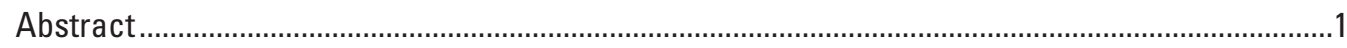

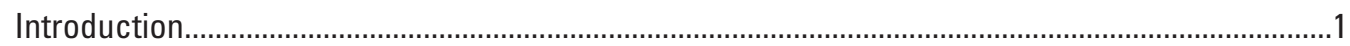

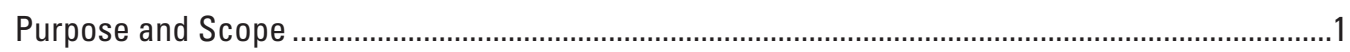

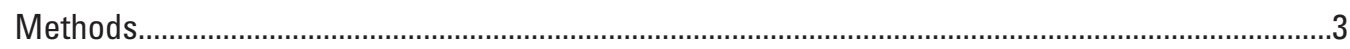

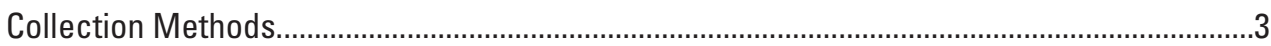

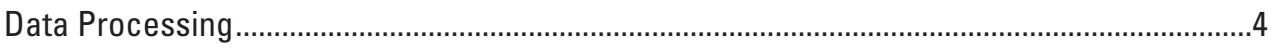

Distribution of Water-Quality Constituents and Characteristics .......................................................

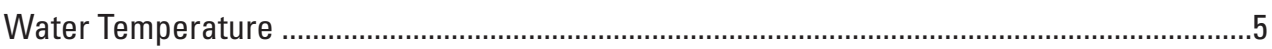

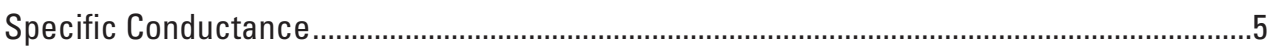

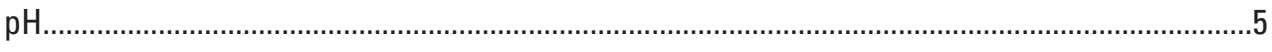

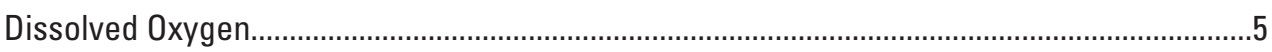

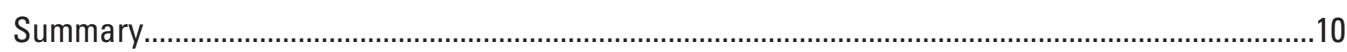

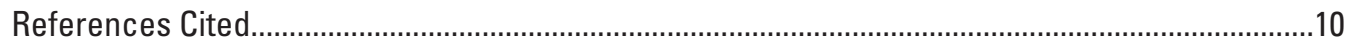

\section{Figures}

1. Map showing autonomous underwater vehicle mission paths, river centerline, and interpolation boundary at the Chemical Recovery Systems site and the East Branch Black River in Elyria, Ohio, March 22, 2021

2. Diagrams and graphs showing three-dimensional path, plot, and longitudinal profiles of water temperature in the East Branch Black River near the Chemical Recovery Systems site in Elyria, Ohio, March 22, 2021

3. Diagrams and graphs showing three-dimensional path, plot, and longitudinal profiles of specific conductance in the East Branch Black River near the Chemical Recovery Systems site in Elyria, Ohio, March 22, 2021

4. Diagrams and graphs showing three-dimensional path, plot, and longitudinal profiles of $\mathrm{pH}$ in the East Branch Black River near the Chemical Recovery Systems site in Elyria, Ohio, March 22, 2021

5. Diagrams and graphs showing three-dimensional path, plot, and longitudinal profiles of dissolved-oxygen concentration in the East Branch Black River near the Chemical Recovery Systems site in Elyria, Ohio, March 22, 2021..

\section{Tables}

1. Summary of autonomous underwater vehicle missions at the Chemical Recovery Systems site at the East Branch Black River in Elyria, Ohio, March 22, 2021

2. Coordinates of centerline used in the Waterbody Rapid Assessment Tool 


\section{Conversion Factors}

U.S. customary units to International System of Units

\begin{tabular}{|c|c|c|}
\hline Multiply & By & To obtain \\
\hline \multicolumn{3}{|c|}{ Length } \\
\hline inch (in.) & 25.4 & millimeter $(\mathrm{mm})$ \\
\hline foot $(\mathrm{ft})$ & 0.3048 & meter $(\mathrm{m})$ \\
\hline yard (yd) & 0.9144 & meter $(\mathrm{m})$ \\
\hline \multicolumn{3}{|c|}{ Area } \\
\hline acre & 4,047 & square meter $\left(\mathrm{m}^{2}\right)$ \\
\hline
\end{tabular}

International System of Units to U.S. customary units

\begin{tabular}{lcll}
\hline & Multiply & By & To obtain \\
\hline & Length & & \\
\hline meter $(\mathrm{m})$ & 3.281 & foot $(\mathrm{ft})$ & \\
meter $(\mathrm{m})$ & 1.094 & yard $(\mathrm{yd})$ & \\
\hline
\end{tabular}

Temperature in degrees Celsius $\left({ }^{\circ} \mathrm{C}\right)$ may be converted to degrees Fahrenheit $\left({ }^{\circ} \mathrm{F}\right)$ as follows: ${ }^{\circ} \mathrm{F}=\left(1.8 \times{ }^{\circ} \mathrm{C}\right)+32$.

Temperature in degrees Fahrenheit $\left({ }^{\circ} \mathrm{F}\right)$ may be converted to degrees Celsius $\left({ }^{\circ} \mathrm{C}\right)$ as follows: ${ }^{\circ} \mathrm{C}=\left({ }^{\circ} \mathrm{F}-32\right) / 1.8$.

\section{Datum}

Vertical coordinate information is referenced to the North American Vertical Datum of 1988 (NAVD 88).

Horizontal coordinate information is referenced to the North American Datum of 1983 (NAD 83).

\section{Supplemental Information}

Specific conductance is given in microsiemens per centimeter at 25 degrees Celsius ( $\mu \mathrm{S} / \mathrm{cm}$ at $\left.25^{\circ} \mathrm{C}\right)$.

Concentrations of chemical constituents in water are given in milligrams per liter ( $\mathrm{mg} / \mathrm{L})$. 


\section{Abbreviations}

$\begin{array}{ll}\text { AUV } & \text { autonomous underwater vehicle } \\ \text { CRS } & \text { Chemical Recovery Systems } \\ \text { EPA } & \text { U.S. Environmental Protection Agency } \\ \text { sonar } & \text { sound navigation and ranging } \\ \text { USGS } & \text { U.S. Geological Survey }\end{array}$





\title{
Water-Quality Distributions in the East Branch Black River near the Chemical Recovery Systems Site in Elyria, Ohio, 2021
}

\author{
By Jordan L. Wilson and Edward G. Dobrowolski
}

\section{Abstract}

Autonomous underwater vehicles are uniquely designed to provide spatially dense water-quality data along with bathymetry and velocimetry. The U.S. Environmental Protection Agency Region 5 requested technical assistance from the U.S. Geological Survey in support of ongoing investigations at the Chemical Recovery Systems site to collect spatially dense water-quality and bathymetry data in the East Branch Black River in Elyria, Ohio. This report was prepared in cooperation with the U.S. Environmental Protection Agency to present the results of the autonomous underwater vehicle survey near the Chemical Recovery Systems site on March 22, 2021. Plots of distributions of water temperature, specific conductance, $\mathrm{pH}$, and dissolved oxygen are presented that may help guide and focus future U.S. Environmental Protection Agency efforts at the site to determine the degree of groundwater/surface-water interaction.

\section{Introduction}

Spatially dense sampling of water-quality constituents and characteristics can be an important component in understanding chemo-hydrodynamics in rivers and lakes. Autonomous underwater vehicles (AUVs) are uniquely designed to provide such spatially dense water-quality data along with bathymetry and velocimetry. Although designed originally for oceanographic applications, AUVs have been used in several freshwater applications (Jackson, 2013a, b; Jackson and Reneau, 2014; Vonins and Jackson, 2017; Conrads and others, 2018; Crain and others, 2019).
The U.S. Environmental Protection Agency (EPA) Region 5 requested technical assistance from the U.S. Geological Survey (USGS) in support of EPA investigations at the Chemical Recovery Systems (CRS) site in Elyria, Ohio (fig. 1), to collect spatially dense water-quality and bathymetry data in the East Branch Black River next to the CRS site. The site consists of 2.5 acres of former industrial uses including a manufactured gas plant, a coal company, and a spent solvent processing facility (EPA, 2021). The East Branch Black River and Locust Street define the western and eastern boundaries of the site, respectively. Land use to the west of the East Branch Black River includes a mixture of residential and commercial use, whereas the area directly north, south, and east is industrial. Groundwater beneath the site is thought to discharge to the East Branch Black River, and spatially dense distributions of water-quality data collected from an AUV may aid in interpreting the potential degree of groundwater/surface-water interaction.

\section{Purpose and Scope}

This report was prepared in cooperation with the EPA to present the results of an AUV survey at the CRS site on March 22, 2021. Plots of spatial distributions of water temperature, specific conductance, $\mathrm{pH}$, and dissolved oxygen are presented that may help guide and focus future EPA efforts at the site to determine the degree of groundwater/surface-water interaction. 


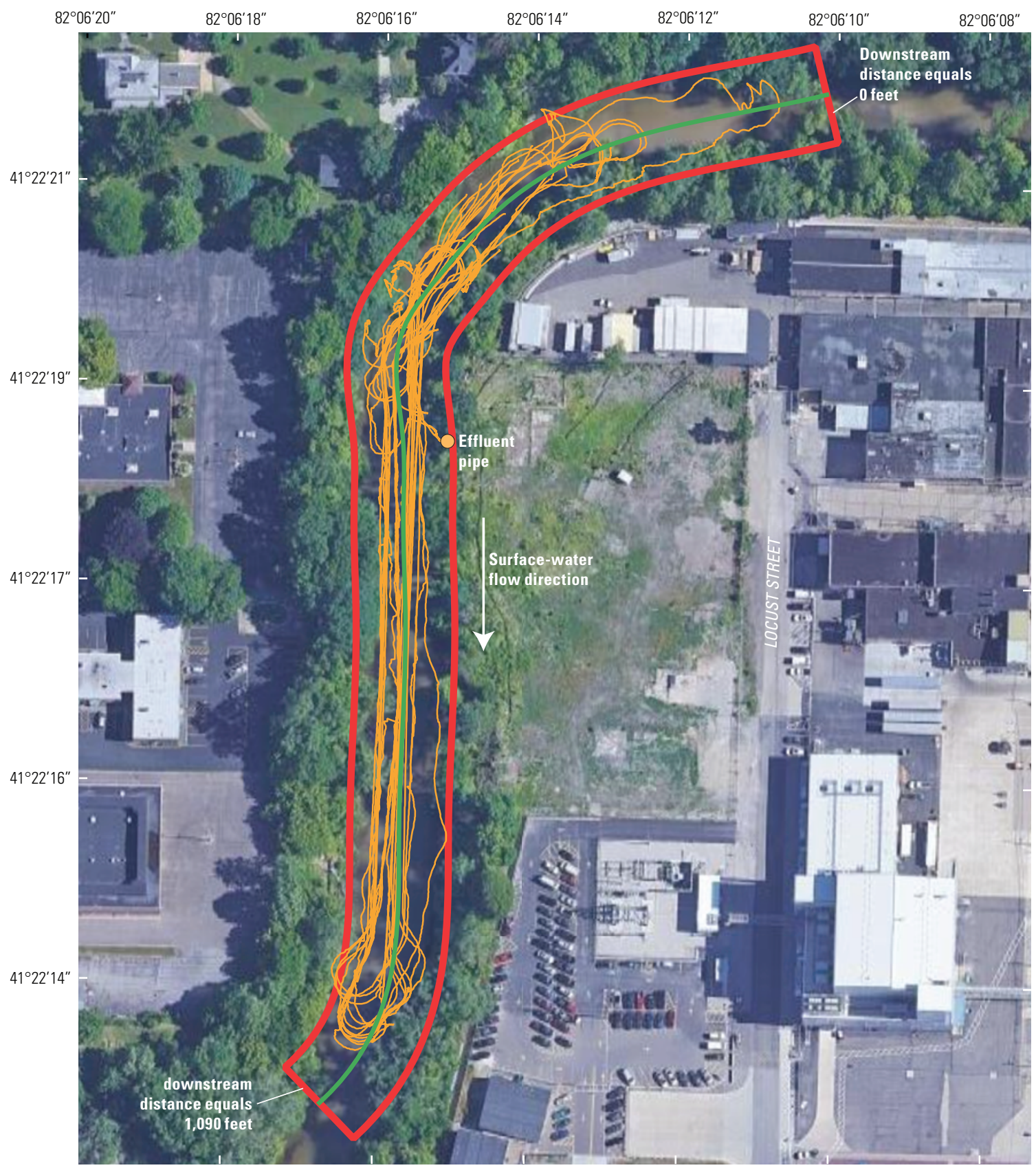

Base map data from Google, 2021

Universal Transverse Mercator projection, zone 17

Horizontal coordinate information referenced to the North American Datum of 1983 (NAD 83)
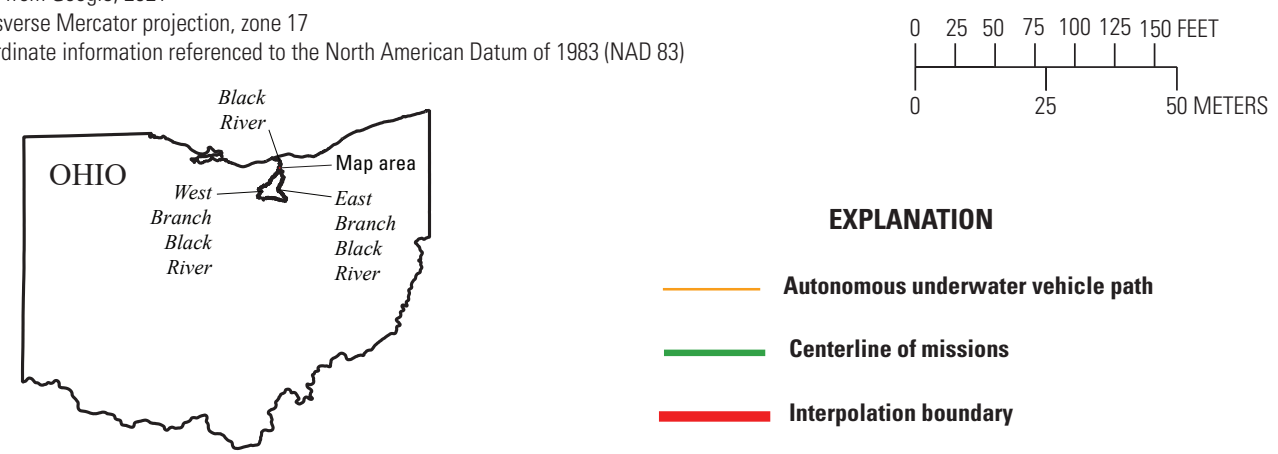

EXPLANATION

Autonomous underwater vehicle path

Centerline of missions

Interpolation boundary

Figure 1. Autonomous underwater vehicle mission paths, river centerline, and interpolation boundary at the Chemical Recovery Systems site and the East Branch Black River in Elyria, Ohio, March 22, 2021. 


\section{Methods}

To provide the EPA with spatially dense water-quality data, the USGS collected data from a series of AUV missions within a stretch of the East Branch Black River and directly next to the CRS site on March 22, 2021, between about 12:30 and 17:30 eastern standard time. Weather on March 22 was generally sunny and warm, and all missions were done on the falling limb of the hydrograph after a storm the previous week on March 20, 2021 (USGS streamgage 04200500; USGS, 2021). The following sections detail the methods used in the collection and processing of AUV data. All AUV data discussed in this report or shown in plots, including waterquality, bathymetry, and sound navigation and ranging (sonar) imaging data, are available as a USGS data release (Wilson and Dobrowolski, 2021).

\section{Collection Methods}

A YSI IVER3 EcoMapper AUV (YSI, Inc., Yellow Springs, Ohio) was used to collected water-quality and bathymetric data at 1 -second intervals. Water-quality data were measured with a YSI EXO1 sonde mounted in the nose cone of the AUV and include water temperature (in degrees Celsius), specific conductance (in microsiemens per centimeter at 25 degrees Celsius), $\mathrm{pH}$ (in standard units), and dissolved oxygen (in milligrams per liter). Bathymetric data were measured using an on-board depth sounder and pressure transducer. Sonar imaging was collected using a StarFish 452F side-scan sonar unit (Blueprint Subsea, Cumbria, United Kingdom) at 450 kilohertz set to a range of 30 meters. Further details regarding the operation and description of the EcoMapper can be found in Jackson (2013a).
The temperature sensor underwent a National Institute of Standards and Technology 5-point temperature check within a 12-month period before the study. Individual sensors for specific conductance, $\mathrm{pH}$, and dissolved oxygen were checked for calibration drift at the beginning of data collection. No formal calibration checks were done on the density and pressure sensors. Methods from the manufacturer (YSI, Inc., 2017) and those outlined in chapter 6 of the USGS national field manual (USGS, variously dated) were followed for calibration checks. Calibration drift was not checked at the end of data collection because the EXO1 sonde was damaged and broke off the EcoMapper AUV during the final mission and could not be retrieved.

To characterize the vertical distribution of water-quality, several missions were planned to target different parts of the water column (table 1). First, a surface mission was done to delineate the rough boundary of the river that the AUV could operate (mission 1). Next, a mission was done 1 meter below the surface to obtain sonar imaging of the subsurface (mission 2). Next, undulating missions were done to characterize the vertical distribution of water quality in the river (missions 3-6). Lastly, two missions were done at fixed heights of 1 and 0.5 meter above the bed of the river to best characterize water quality near the groundwater/surface-water interface (missions 7 and 8, respectively). Throughout each survey, the AUV would partially collide with woody debris along the sides of the river, and a remote control was used to take manual control and redirect the AUV out of the path of debris to ensure no data were lost, and the mission was subsequently continued.

An actively flowing effluent pipe originating from the CRS site along the eastern boundary of the river reach was identified during the survey (fig. 1). The AUV surveyed near the effluent pipe during mission 6 .

Table 1. Summary of autonomous underwater vehicle missions at the Chemical Recovery Systems site at the East Branch Black River in Elyria, Ohio, March 22, 2021.

\begin{tabular}{|c|c|c|c|c|}
\hline $\begin{array}{l}\text { Mission } \\
\text { number }\end{array}$ & Mission name & Type & $\begin{array}{c}\text { Depth, in } \\
\text { meters }\end{array}$ & Dataset truncation \\
\hline 1 & 20210322-163344-CRS_Surface_0m-IVER3-3085 & Surface & 0 & - \\
\hline 2 & 20210322-180945-CRS_Surface-IVER3-3085 & Constant depth & 1 & - \\
\hline 3 & 20210322-190655-CRS_Undulate_1m_5m-IVER3-3085 & Undulate & $1-5$ & $\begin{array}{l}\text { After index 2,226 in } \\
\text { dataset }\end{array}$ \\
\hline 4 & 20210322-193728-CRS_Undulate_1m_5m-IVER3-3085 & Undulate & $1-5$ & $\begin{array}{l}\text { After index } 1,050 \text { in } \\
\text { dataset }\end{array}$ \\
\hline 5 & 20210322-200639-CRS_Undulate_1m_5m-IVER3-3085 & Undulate & $1-5$ & - \\
\hline 6 & 20210322-202300-CRS_Undulate_1m_5m-IVER3-3085 & Undulate & $1-5$ & - \\
\hline 7 & 20210322-205856-CRS_HFB_revised-IVER3-3085 & $\begin{array}{l}\text { Height from bot- } \\
\text { tom }\end{array}$ & 1 & $\begin{array}{l}\text { After index } 1,316 \text { in } \\
\text { dataset }\end{array}$ \\
\hline 8 & 20210322-213021-CRS_HFB_revised_halfm-IVER3-3085 & $\begin{array}{l}\text { Height from bot- } \\
\text { tom }\end{array}$ & 0.5 & $\begin{array}{l}\text { After index } 212 \text { in } \\
\text { dataset }\end{array}$ \\
\hline
\end{tabular}




\section{Data Processing}

All AUV data were processed based on the routines described in Jackson (2013a). Briefly, VectorMap (YSI, Inc., Yellow Springs, Ohio) was used to correct for positional drift while underwater, and then the water-quality data were screened to identify spikes (outliers) that are uncharacteristic of the natural system or that are four times the standard deviation of a 60 -second moving window average of that data. Smoothing was not applied to the data. Finally, sensor lag (the response time of the sensor) was corrected using standard lag times of $-2.1,-0.5,-7.1$, and -5.5 seconds for water temperature, specific conductance, $\mathrm{pH}$, and dissolved oxygen, respectively, from Jackson (2013a) because of the large horizontal heterogeneity in water-quality constituents and characteristics, which prevented calculation of lag times from vertical profiles. All data were then combined into a single comma-separatedvalues file (Wilson and Dobrowolski, 2021).

Plots presented in this report were created using the Python software Waterbody Rapid Assessment Tool (WaterRAT; Huffman, 2021). WaterRAT was designed for ingesting AUV data and creating three-dimensional plots to better visualize the data. Plots of measured water-quality constituents along the trajectory of the AUV, interpolated plots of the average value of each constituent within each model cell, and longitudinal cross-sections through the interpolated volume along the river are all provided as output from WaterRAT. A line feature, which is used to create the interpolation boundary (or the spatial extent to conduct three-dimensional interpolation) was created in QGIS (QGIS Development Team, 2021) roughly through the center of all the missions to use as input to WaterRAT (table 2). Step sizes, which set the size of each block in the interpolation in which constituents are averaged, of 20, 20, and 1 feet were used in the $\mathrm{x}, \mathrm{y}$, and $\mathrm{z}$ directions, respectively; a vertical aspect ratio (or the ratio of the vertical to horizontal dimension) of 20 was used to better visualize the vertical distribution of constituents; and the river width was
Table 2. Coordinates of centerline used in the Waterbody Rapid Assessment Tool (WaterRAT; Huffman, 2021).

[See the centerline in figure 1]

\begin{tabular}{cc}
\hline Latitude & Longitude \\
\hline 41.3727344012951 & -82.1030402894675 \\
41.3726529807683 & -82.1035326897962 \\
41.3725676830735 & -82.1038661262392 \\
41.3724203506917 & -82.1041491594990 \\
41.3722846498137 & -82.1043042462167 \\
41.3721120916080 & -82.1044475560368 \\
41.3718578850919 & -82.1044338890198 \\
41.3716721778911 & -82.1044298653569 \\
41.3714189785656 & -82.1044186491548 \\
41.3711760901088 & -82.1044214741315 \\
41.3709044142314 & -82.1044307454883 \\
41.3706278535621 & -82.1044338890198 \\
41.3701948562928 & -82.1046842086751 \\
41.3727344012951 & -82.1030402894675 \\
\hline
\end{tabular}

set at 90 feet. Water-quality and bathymetry readings containing outliers were removed before import into WaterRAT so data would plot correctly; however, removing outliers sometimes left model boxes without data, resulting in missing areas in bathymetry and water-quality data. Plots of specific conductance, $\mathrm{pH}$, and dissolved oxygen were constructed using all combined data, and plots of water temperature were constructed using mission 6 data because of the transient behavior of temperature and concerns about thermal stratification of the river caused by air temperature, convoluting thermal stratification caused by groundwater/surface-water interaction (table 1). Cross-sectional plots at $0,20,40$, and 60 feet east of the centerline (fig. 1) were created to show the vertical distribution of water-quality constituents near the CRS site. 


\section{Distribution of Water-Quality Constituents and Characteristics}

Distribution plots of water temperature, specific conductance, $\mathrm{pH}$, and dissolved oxygen collected using the AUV are presented in this section. These plots are presented to support future interpretation of potential groundwater/surface-water exchange at the CRS site and guide future efforts by the EPA at the site.

\section{Water Temperature}

Water temperature ranged from 9.4 to 11.2 degrees Celsius. The smallest values of water temperature were near an effluent pipe on the northwest part of the CRS site (fig. 2). The largest values of water temperature were near the water surface.

\section{Specific Conductance}

Specific conductance ranged from 508 to 1,150 microsiemens per centimeter at 25 degrees Celsius. The smallest values of specific conductance were near the water surface. The largest values of specific conductance were near the effluent pipe; otherwise, specific conductance was generally uniform within the interpolation boundary (fig. 3).

\section{pH}

Values of $\mathrm{pH}$ ranged from 7.3 to 8.0 standard units. The smallest values of $\mathrm{pH}$ were near the effluent pipe, but the distribution of $\mathrm{pH}$ within the interpolation boundary was generally uniform and alkaline (fig. 4). The largest values of $\mathrm{pH}$ were farther away from effluent pipe.

\section{Dissolved Oxygen}

Dissolved-oxygen concentrations ranged from 4.4 to 11.2 milligrams per liter. The lowest dissolved-oxygen concentrations were at the bottom of the river about 200 feet upstream from the effluent pipe (fig. 5); otherwise, concentrations were fairly uniform and consistently greater than 10 milligrams per liter. Low dissolved-oxygen concentrations were measured when the AUV was surveying close to the bottom of the river for a brief period. 
$\boldsymbol{A}$

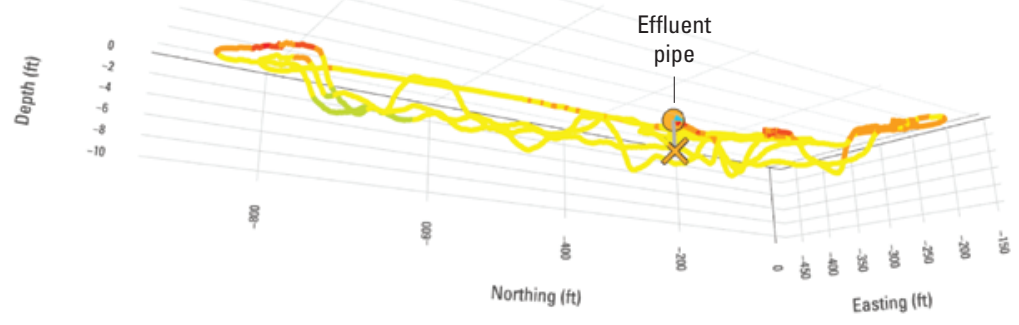

EXPLANATION

$\boldsymbol{B}$
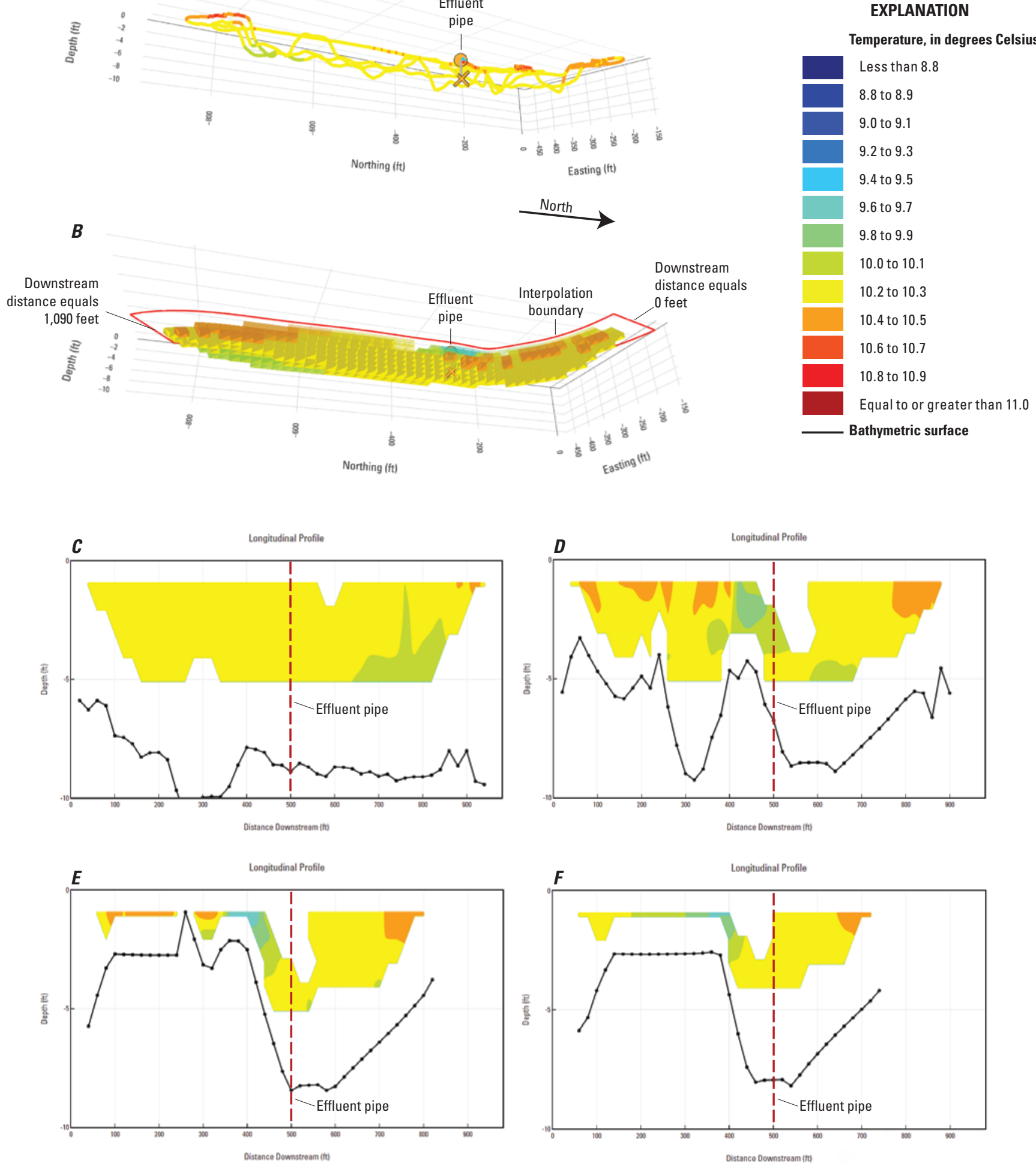

Figure 2. Three-dimensional path, plot, and longitudinal profiles of water temperature in the East Branch Black River near the Chemical Recovery Systems site in Elyria, Ohio, March 22, 2021. A, path. B, plot. Profiles, $C, 0$ feet; $D, 20$ feet; $E, 40$ feet; and $F, 60$ feet east of the mission centerline. 


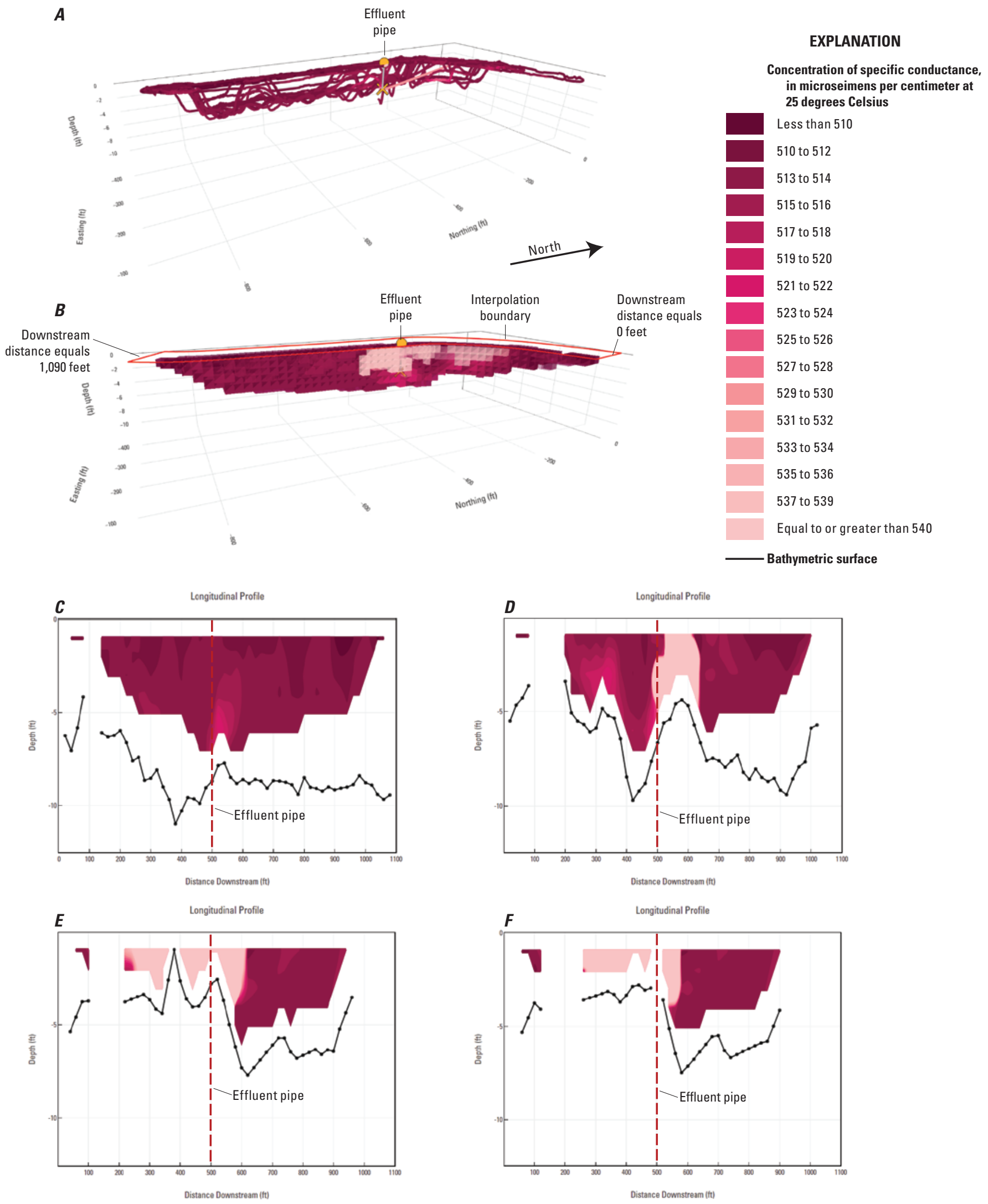

Figure 3. Three-dimensional path, plot, and longitudinal profiles of specific conductance in the East Branch Black River near the Chemical Recovery Systems site in Elyria, Ohio, March 22, 2021. A, path. B, plot. Profiles, $C, 0$ feet; $D, 20$ feet; $E$, 40 feet; and $F, 60$ feet east of the mission centerline. 


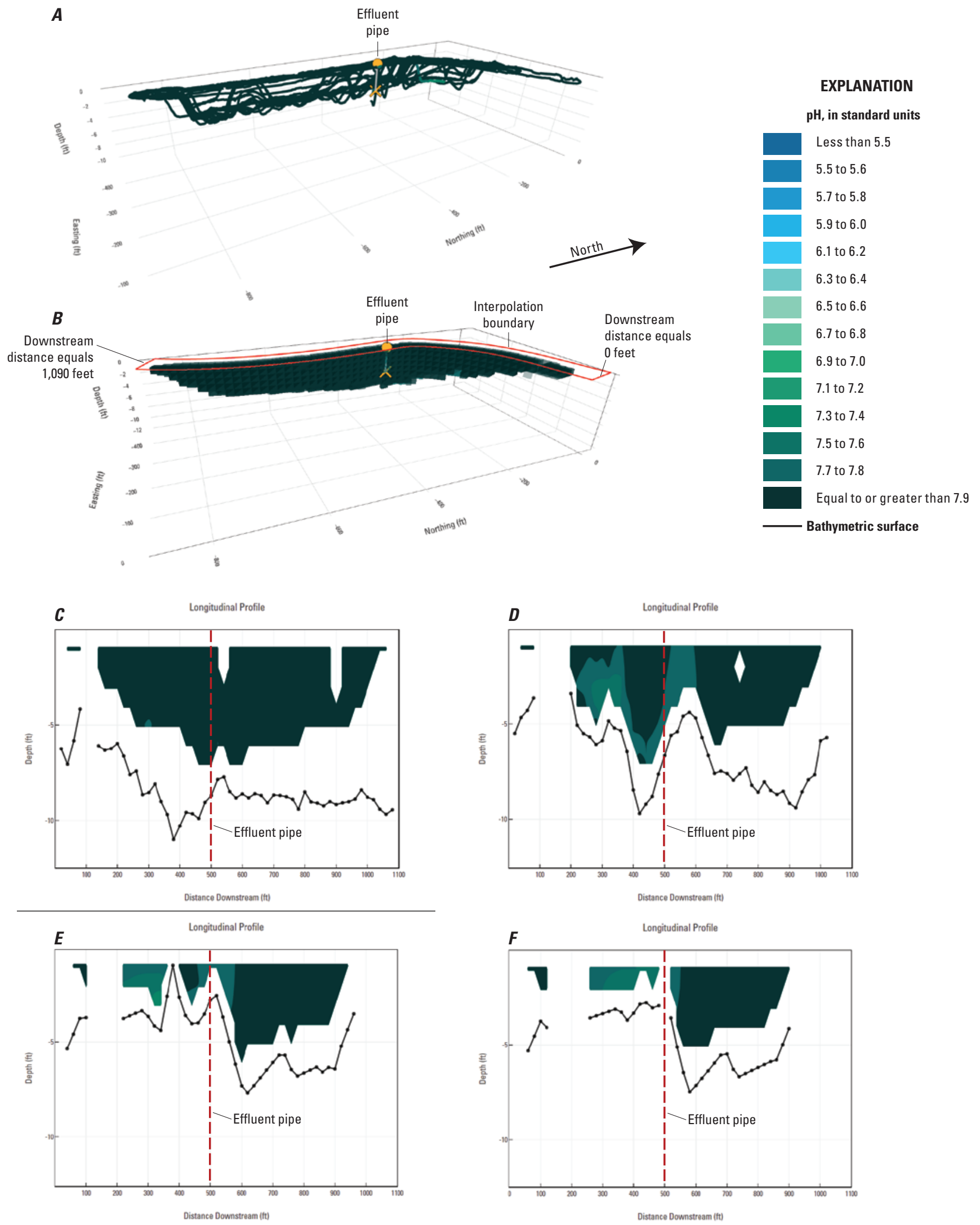

Figure 4. Three-dimensional path, plot, and longitudinal profiles of $\mathrm{pH}$ in the East Branch Black River near the Chemical Recovery Systems site in Elyria, Ohio, March 22, 2021. $A$, path. $B$, plot. Profiles, $C, 0$ feet; $D, 20$ feet; $E$, 40 feet; and $F, 60$ feet east of the mission centerline. 


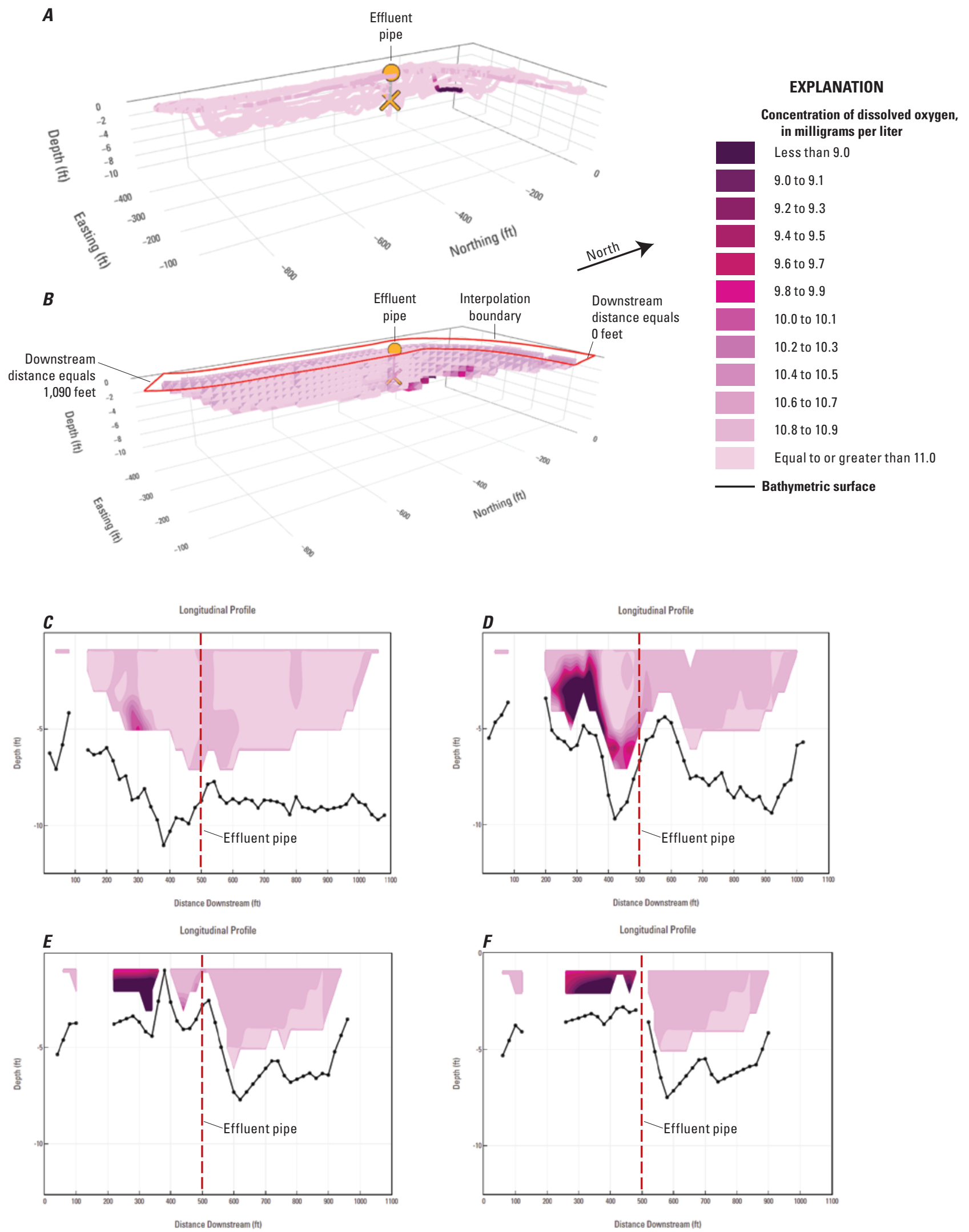

Figure 5. Three-dimensional path, plot, and longitudinal profiles of dissolved-oxygen concentration in the East Branch Black River near the Chemical Recovery Systems site in Elyria, Ohio, March 22, 2021. A, path. $B$, plot. Profiles, $C, 0$ feet; $D, 20$ feet; $E$, 40 feet; and $F, 60$ feet east of the mission centerline. 


\section{Summary}

Autonomous underwater vehicles are uniquely designed to provide spatially dense water-quality data along with bathymetry and velocimetry. The U.S. Environmental Protection Agency Region 5 requested technical assistance from the U.S. Geological Survey in support of ongoing investigations at the Chemical Recovery Systems site to collect spatially dense water-quality and bathymetry data in the East Branch Black River in Elyria, Ohio. This report was prepared in cooperation with the U.S. Environmental Protection Agency to present the results of the autonomous underwater vehicle survey near the Chemical Recovery Systems site on March 22, 2021. Plots of distributions of water temperature, specific conductance, $\mathrm{pH}$, and dissolved oxygen are presented that may help guide and focus future U.S. Environmental Protection Agency efforts at the site to determine the degree of groundwater/surface-water interaction.

\section{References Cited}

Conrads, P.A., Journey, C.A., Petkewich, M.D., Lanier, T.H., and Clark, J.M., 2018, Characterization of water quality in Bushy Park Reservoir, South Carolina, 2013-15: U.S. Geological Survey Scientific Investigations Report 2018-5010, 175 p. [Also available at https://doi.org/10.3133/sir20185010.]

Crain, A.S., Boldt, J.A., Bayless, E.R., Bunch, A.R., Young, J.L., Thomason, J.C., and Wolf, Z.L., 2019, Potential interaction of groundwater and surface water including autonomous underwater vehicle reconnaissance at Nolin River Lake, Kentucky, 2016: U.S. Geological Survey Scientific Investigations Report 2019-5075, 36 p. [Also available at https://doi.org/10.3133/sir20195075.]

Huffman, B., 2021, Waterbody Rapid Assessment Tool (WaterRAT) (ver. 1.0.0): GitHub, Python application, accessed March 20, 2021, at https://github.com/bhuffman-usgs/ waterrat.

Jackson, P.R., 2013a, Circulation, mixing, and transport in nearshore Lake Erie in the vicinity of Villa Angela Beach and Euclid Creek, Cleveland, Ohio, September 11-12, 2012: U.S. Geological Survey Scientific Investigations Report 2013-5198, 34 p. [Also available at https://doi.org/10.3133/sir20135198.]

Jackson, P.R., 2013b, Integrated synoptic surveys using an autonomous underwater vehicle and manned boats: U.S. Geological Survey Fact Sheet 2013-3018, 4 p. [Also available at https://doi.org/10.3133/fs20133018.]
Jackson, P.R., and Reneau, P.C., 2014, Integrated synoptic surveys of the hydrodynamics and water-quality distributions in two Lake Michigan rivermouth mixing zones using an autonomous underwater vehicle and a manned boat: U.S. Geological Survey Scientific Investigations Report 2014-5043, 33 p. [Also available at https://doi.org/10.3133/sir20145043.]

QGIS Development Team, 2021, QGIS Geographic Information System (ver. 3.4.2, Maderia): Open Source Geospatial Foundation Project software, accessed April 2021 at https://qgis.org/.

U.S. Environmental Protection Agency [EPA], 2021, Chemical Recovery Systems Elyria, OH - Cleanup activities: U.S. Environmental Protection Agency web page, accessed April 12, 2021, at https://cumulis.epa.gov/supercpad/ SiteProfiles/index.cfm?fuseaction=second.Cleanup\&id= 0504384\#bkground.

U.S. Geological Survey [USGS], [variously dated], National field manual for the collection of water-quality data: U.S. Geological Survey Techniques of Water-Resources Investigations, book 9, chaps. A1-A10, accessed April 2021 at https://www.usgs.gov/mission-areas/water-resources/ science/national-field-manual-collection-water-qualitydata-nfm?qt-science_center_objects $=0 \#$ qt-science center_objects.

U.S. Geological Survey [USGS], 2021, USGS 04200500 Black River at Elyria OH, in USGS water data for the Nation: U.S. Geological Survey National Water Information System database, accessed April 12, 2021, at https://doi.org/ 10.5066/F7P55KJN. [Site information directly accessible at https://waterdata.usgs.gov/oh/nwis/uv?site_no $=04200500$.]

Vonins, B.L., and Jackson, P.R., 2017, Response of currents and water quality to changes in dam operations in Hoover Reservoir, Columbus, Ohio, August 24-28, 2015: U.S. Geological Survey Scientific Investigations Report 2017-5027, 62 p. [Also available at https://doi.org/10.3133/sir20175027.]

Wilson, J.L., and Dobrowolski, E.G., 2021, Autonomous underwater vehicle water-quality and sonar measurements in the East Branch Black River near Elyria, Ohio, 2021: U.S. Geological Survey data release, https://doi.org/ 10.5066/P9FEBCBY.

YSI, Inc., 2017, EXO user manual advanced water quality monitoring platform: YSI, Inc., 153 p., accessed April 2021 at https:/www.ysi.com/file\%20library/documents/manuals/ exo-user-manual-web.pdf. 
For more information about this publication, contact:

Director, USGS Central Midwest Water Science Center

1400 Independence Road

Rolla, MO 65401

573-308-3667

For additional information, visit: https://www.usgs.gov/centers/cmwater

Publishing support provided by the Rolla Publishing Service Center 


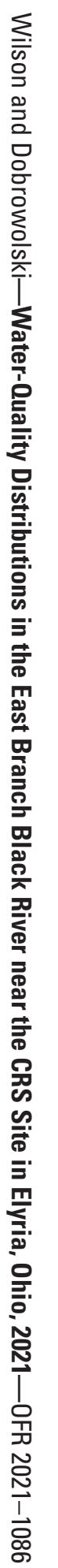

